\title{
The Rise of the New Western in the 1960s: E.L. Doctorow's Welcome to Hard Times
}

\section{Arthur Jaupaj}

\section{OpenEdition}

\section{Journals}

Electronic version

URL: https://journals.openedition.org/ejas/3303

DOI: $10.4000 /$ ejas.3303

ISSN: 1991-9336

Publisher

European Association for American Studies

\section{Electronic reference}

Arthur Jaupaj, "The Rise of the New Western in the 1960s: E.L. Doctorow's Welcome to Hard Times", European journal of American studies [Online], 3-2 | 2008, document 6, Online since 11 November 2008, connection on 08 July 2021. URL: http://journals.openedition.org/ejas/3303 ; DOI: https://doi.org/ 10.4000/ejas.3303

This text was automatically generated on 8 July 2021.

Creative Commons License 


\title{
The Rise of the New Western in the 1960s: E.L. Doctorow's Welcome to Hard Times
}

\author{
Arthur Jaupaj
}

\section{Introduction}

1 The 1960s are often typified as turbulent years marked by accumulated and repressed energy breaking loose to "flood" preconceived absolutes and media-based mentalities. The so called "counter-culture" revolution, with its innovative artistic explosion and general distrust towards master narratives, generated numerous social and political implications which permanently shaped the expectations of future generations. In the field of literature and film, it also initiated a re-evaluation of the literary mythology surrounding the Western, due to the latter's outdated, almost clichéd narrative structure and its increasingly unappealing imagery. Above all, the "counter-culture" revolution of the 1960s irrevocably revised the fiction-writing process itself.

In these circumstances, the Western managed to survive by parodying its own formula restrictions and distorting the classic reader's expectations of the genre. The Western also became part and parcel of the artistic innovations at hand as it was taken up even by traditionally non-Western writers such as Thomas Berger (Little Big Man, 1964), Ishmael Reed (Yellow Back Radio Broke Down, 1968) and E.L. Doctorow, to name a few. These authors turned to the most popular genre of the time with a double mission: to both deconstruct it, and to use it to revive the traditional novel-writing process through the use of Western elements. The traditional novel, like the Western, was commonly regarded to have exhausted itself.

The 1960s therefore marked the rise of a new genre, referred to by Leslie Fiedler in The Return of the Vanishing American (1968) as the 'New Western,' or by John G. Cawelti in The Six-Gun Mystique Sequel (1999) as the 'Post-Western.' E. L. Doctorow's striking Welcome to Hard Times (1960) exemplifies perfectly the New Western or Post-Western by blending both Western and meta-fictional elements into a more sustainable fictional and mythical entity, in doing so revealing an alternative and more intriguing Western 
history. Above all, Welcome to Hard Times revitalized the "literature of exhaustion" and "silence," as John Barth and Ihab Hassan respectively labeled it in the 1960s, by creating real fiction out of the remnants of the out-dated genre. Welcome to Hard Times is analyzed here not simply as another case where the west and/or Western have been demythologized, but as a western novel which operates through the paradigms of the 1960s and beyond. In this context, Welcome to Hard Times reflects Doctorow's initial and all-encompassing interest in re-writing the past, and above all, his belief in language as the primary myth-maker.

4 This article summarizes the main analyses already published on Doctorow's novel, and looks to move beyond them to tackle other issues related to this forerunner of the New Western. In particular, it focuses on the metafictional elements and new features of the Western as depicted by Doctorow. As his first novel, Welcome to Hard Times remains an exemplary work not only for the revival of the western genre and novel-writing itself, but also for gaining a better understanding of Doctorow's approach as the writer of "historical fiction."

\section{Periodizing the Literary 1960 s}

5 As is widely known, the legacy of the 1960s both in America and Europe is closely associated with the contesting and uprooting of preconceived cultural and artistic values, replacing them with more liberal, experimental and revolutionary paradigms pertaining to almost all aspects of social life. ${ }^{1}$ What is more important, the 1960 s are regarded as the era which gave birth to postmodernism and the crisis of representation as reflected in such assumptions as "the death of the author," "everything is constructed within language," and "knowledge' is merely a means of preserving power" (Marwick 1998: 290). ${ }^{2}$ What triggered such an unprecedented upheaval and turmoil? For Marwick, the answer lies in the so-called "rigid fifties":

[R]igid social hierarchy; subordination of women to men and children to parents; repressed attitudes toward sex; racism; unquestioning respect for the authority in the family, education, government, the law, and religion, and for the nation-state, the national flag, the national anthem; Cold War hysteria; a strict formalism in language, etiquette, and dress codes; a dull and cliché-ridden popular culture, most obviously in popular music, with its boring big bands and banal ballads (Marwick 1998: 3)

In the United States, the rupture was mainly caused by a mounting distrust towards the official media and media-generated cultural images. Raymond Federman, an American postmodern writer and essayist, labels the 1960s as the "era of suspicion" and argues that it "took certain blunders of the Johnson administration, and subsequently the manipulations and lies of the Nixon administration, and of course the Vietnam War, and the Watergate debacle, to awaken America from its mass media state of illusion and optimism" (Federman 1993: 25). Ihab Hassan in his introduction to Rumors of Change: Essays of Five Decades (1995) argues along similar lines about the post-Kennedy era:

Part of America sank forever there; part of it lives on, torn, tortured, to this day. But another part released itself in extravagant energies: the ecological revolution; the Berkley free-speech movement; SDS and the Weathermen; the Student Non-violent Coordinating Committee, the Congress on Racial Equality, and the Black Panthers; the Grey Panthers; women's and gay liberation; Chicano and red power; hippies and yippies, freaks and crazies; rock, psychedelics, occultism, the Woodstock nation; dropouts and communes spreading from Haight Ashbury to Staten Island....It is a 
miracle that anyone survived the shocks, exaltations, cataclysms, apocalypses of 1968 alone. (xviii)

7 By simply casting a quick glance at some of the works published in the 1960s in America and Europe one may get enough evidence of the general mistrust and tension floating in the air:

Advertisement for Myself (1959), No! In Thunder (1960), Growing up Absurd (1960), Silence (1961), An Age of Enormity (1962), Silent Spring (1962), The Fire Next Time (1963), The Feminine Mystique (1963), Understanding Media (1964), One Dimensional Man (1964), The Autobiography of Malcolm X (1965), Love's Body (1966), Against Interpretation (1966), A Year from Monday (1967), Soul on Ice (1968), Armies of the Night (1968), The Electric Kool-Aid Acid Test (1968), Revolution for the Hell of it (1968), The Population Bomb (1968), The Politics of Ecstasy (1968), Education and Ecstasy (1968), The Making of a Counter Culture (1969), Utopia or Oblivion (1969), The Female Eunuch (1970), Do It (1970), Future Shock (1970) (Hassan 1995: xviii)

8 The 1960s were a time when the long-held literary and rational conventions broke loose and language was losing the ability to convey any meaning. John Barth, for instance, coined the self-suggestive term "Literature of Exhaustion," and Ronald Sukenick declared the novel dead by arguing that "The contemporary writer - the writer who is actually in touch with the life of which he is part - is forced to start from scratch: Reality doesn't exist, time doesn't exist, personality doesn't exist. God was the omniscient author, but he died; now no one knows the plot, and since our reality lacks the sanction of a creator, there is no guarantee as to the authenticity of the received version" (quoted in Federman 1993: 115).

9 As such, the "art explosion" irrevocably changed the previous role art had played, the way art had been produced and the media art had used to depict reality. Arthur Marwick highlights several attitudes to the appreciation of art that pertained specifically to the era, and these could easily be regarded as distinctive features of the postmodern itself. These ranged from the blurring of boundaries between genres and the indeterminacy of meaning to the revolutionary stance of considering the work of art as an experiment. ${ }^{3}$

10 Led by such principles (or lack of principles), literary endeavors purposely blurred the distinction between reality and fiction through an intensive use of self-reflexive elements, fragmentation, parody, irony, discontinuity, black humor, farce, explicit sexuality and media-related images. Even the New Western, despite its deconstructive agenda, was primarily launched and embraced by non-Western writers in order to revive the new novel writing process initiated in the early 1960s.

3. Featuring the New Western

11 The 1960s marked the decline of the so-called grand or master narratives, and the popularity of the formula Western suffered the most due to an increasing incredulity towards orthodox historical accounts and the apparently unsustainable mythology of the West. John G. Cawelti in The Six-Gun Mystique Sequel (1999) argues that the decline of the Western was brought about by a "growing uncertainty about American uniqueness and about the special place of the West in establishing that uniqueness" (Cawelti 1999: 6). James K. Folsom in The American Western Novel (1966) links the decline of the most popular genre in America with on the one hand the rise in popularity of science fiction and the detective story, and on the other the misapprehension of the genre's intentions as a fable (Folsom 1966: 29). 
12 It is clear that the elements of the classic genre, even though reversed and parodied to the extreme, began to be utilized for different ends by both Western and non-Western writers alike as they embarked on a parody of the West and the Western in order to challenge not simply this redundant genre but, more importantly, to revive fiction writing itself. Doctorow belongs to this category of writers who turned to the neglected Western in the 1960s in order to make real fiction out of the remnants of tradition. Therefore, the Western in the 1960s proliferated into different kinds of representations. Christine Bold has identified three main types of Westerns. First, the “elegiac Western," epitomized by Edward Abbey's The Brave Cowboy (1956) and Arthur Miller's The Misfits (1961) where the hero or the heroine cannot possibly survive in the twentieth century despite her/his heroic acts. Second, the "Unheroic Western," exemplified by Larry McMurtry's Horseman, Pass By (1961) where a complete reversal of the conventional heroic West/Western is re-presented. Third, the "anti-Western Western," such as E.L. Doctorow's Welcome to Hard times (1960), Ishmael Reed's Yellow Back Radio Broke Down (1969), John Schlesinger's Midnight Cowboy (1965), and Thomas Berger's Little Big Man (1964), which made serious fiction out of the remnants of the conventional Western (Bold 1987: 157-158).

In addition, the anti-Western Western undertook to re-construct the superficial representations of the westward expansion and write the western experience anew. In fact, it went even further by questioning the verity of the classic Western due to its incredulity towards the means of representation such as language, time, memory, and narrative itself. As such, it is wiser to believe that the fictional depictions of the New Western tend to be more revealing historical accounts as they blended both fictional and factual elements.

14 The main concern in dealing with the past and Western mythology on the part of the New Western remained the lack of a trustworthy "historical reference" and the existence of simulacra (copies without originals), as Jean Baudrillard labeled it: "Baudrillard argued that today the mass media have neutralized reality by stages: first they reflected it, then they masked and perverted it; next they had to mask its absence; and finally they produced instead the simulacrum of the real, the destruction of meaning and of all relation to reality" (Hutcheon 1989: 33). Here lies the success of the New Western in particular and the new fiction of the 1960s in general, that is, the artist-historian using interchangeably both facts and fiction, thus re-presenting more intriguing and truthful alternative Western histories. In this way the post-Western or the New Western of the 1960s fits perfectly within the "historiographic metafiction" of Linda Hutcheon, as it deconstructed the West and the Western and highlighted the narrative nature of knowledge, "be it historical or fictional" (Hutcheon 1989: 78). In this sense, Welcome to Hard Times aimed to re-present the American West and the Western anew from the high ground of the radical, postmodern mindset of the 1960s.

4. Welcome to Hard Times: Writing as a 'False Document'

15 E. L. Doctorow's Welcome to Hard Times could easily be classified as an atypical classic Western and an exemplary New Western. As a matter of fact, the novel questions the verity of the narrative itself in depicting the past in particular and reality in general. Furthermore, it is argued here that the western experience of endless economic opportunities or the belief of the West as the "Garden of the World" are reduced to being no more than a fraudulent experience. 
To question the verity of the fictional discourse, Doctorow blurs the distinction between fact and fiction: ". . . there is no fiction or nonfiction as we commonly understand the distinction: there is only narrative" (Doctorow 1996: 26). As such, as John G. Parks argues, "It is more useful to see Doctorow's fiction as illustrating what Foucault describes as a 'battle among discourses through discourses' and of what Bakhtin calls 'heteroglossia"' (Parks 1991: 456).

Welcome to Hard Times, even though Doctorow's first work, raises the above-mentioned issues and goes beyond them. Plainly stated, the novel depicts the futile efforts of a man who is creating fiction as he attempts to write history. This departs significantly from the classic Western as "well-wrought American parable" (Williams 1996: 7). The novel traces the futility of the history-recording process due to the failure of memory, language and illusions in creating a sustainable reality and the prevalence of a cyclical violence which eventually leads to the demise of a frontier town in the Dakotas in the second half of the nineteenth century. As Doctorow argues, "So I suppose my view of history is a phenomenological one, and you might call it cynical or pessimistic, you might say it verges on the existential, but there is a saving grace: since history can be composed, you see, then you want to have as many people active in the composition as possible. A kind of democracy of perception" (quoted in Friedl and Schulz 1999: 112).

Such a stance highlights the primary aim of the novel, that is, the failure of narrative to deliver a truthful representation of the past. Likewise, Doctorow warns the reader about the pitfalls of the history-recording process in his seminal essay "False Documents": "There is no history except as it is composed ... Facts are the images of history, just as images are the data of fiction" (Doctorow 1983: 24).

In line with this standpoint, the narrator Blue in Welcome to Hard Times, as a selfappointed mayor, historian and artist, turns to book-keeping accidentally after a former lawyer provides him with the opportunity to do so. Furthermore, his belief in the economic and political prospects of the town play an important role in his decision: "I had taken it upon myself to keep records in case the town ever got large enough to be listed, or in case statehood ever came about. I kept the books and they called me mayor" (Hard Times 12). Yet, Blue's ledgers remain linguistic endeavors in trying to pin down the past on the one hand, and fictional and factual accounts of an elusive truth on the other, as his self-contradictory phrases clearly reveal: "I can't be too clear of that ... .;" "What am I trying to do now ... ? ;" "It is all I can do to remember it for my purposes ...;" "No, maybe I'm not telling it right ...." This is recording reality as "a continuous and circular process of seeing and concealing, recording and denying, a recoil from experience into a consoling but utterly fabricated web of words" (Buscombe 1998: 108). Yet, Blue's failure to represent the past could be regarded as the failure of the means of representation, that is, language, memory and delusions, which are needed to bring order and intelligibility to the chaotic reality of the frontier town Hard Times and beyond.

In fact, throughout the novel, Blue remains a victim of his own preconceived cultural and fictional illusions. Thus, not until the third ledger does he realize the failure of both memory and language in structuring and ordering the multi-layered chaos around him. Nevertheless, Doctorow, the artist, succeeds where Blue, the historian, fails.

21 Firstly, Doctorow's mistrust towards language is revealed in his avoidance of decorative language and embellishments. This is best revealed in the lack of linguistic competence of almost all the characters except Blue, as most of them happen to be immigrants. The 
Bad Man from Bodie / Clay Turner, for instance, even though he succeeds in wrecking the whole town overnight, abstains from articulating a single word. Throughout the novel he utters no words, expressing himself with his cynical laugh and repulsive grinning. In addition, the Indian, John Bear, is depicted as a deaf-mute person who performs his shamanistic deeds effectively and keeps his natural, self-sustaining life intact without needing to communicate or enter into any economic transactions. Even Zar, the whoremaster and pimp, remains a reserved entrepreneur whose motto remains: "money talks."

Secondly, Blue's ledgers are based on memory and punctuated by his never-ending, false illusions of progress in the West. As such, his ledgers could be argued to be unreliable historical documents which "seek to persuade but become something we can neither believe nor disbelieve" (Harpham 1985: 82). As a result, Blue ends his ledgers by contemplating the verity of his ledgers and questioning the existence of a truthful fictional account:

And now I've put down what happened, everything that happened from one end to the other. And it scares me more than death scares me that it may show the truth. But how can it if I've written as if I knew as I lived them which minutes were important and which not; and spoken as if I knew the exact words everyone spoke?

Does the truth come out in such scrawls, so bound by my limits? (Hard Times 210)

Doctorow, through his narrator-historian's ledgers, questions the legacy of his own artistic creation and his personal meaning-making enterprise the same way that Blue questions his potential reader: "Do you think, mister, with all that settlement around you that you're freer than me to make your fate? Do you click your tongue at my story?" (Hard Times 184). Yet, Blue's greatest error as a writer and his personal tragedy, according to Cooper B., "stems from his belief that he, like an alchemist, can make truth" (13) thus failing to move away from the "prison-house of language."

Finally, it is possible to argue that Doctorow the artist succeeds in getting closer to the truth more than Doctorow the historian, as the former fully accepts the failure of his fiction as a truthful representation, while the historian still claims truth and succumbs to the deceptive power of language in depicting the past. By highlighting the emotional and psychic condition of his narrator, as opposed to the historian's search for uncontested facts, Doctorow the artist is in some ways providing a more genuine truth regarding the demise of the frontier town.

5. Welcome to Hard Times: A Violent West

Apart from its striking meta-fictional character, in the sense of the failure of fictional representation to capture objective reality in general and the past in particular, Welcome to Hard Times exemplifies a demythologized Western where violence reigns supreme. In fact, the novel traces the destruction, reconstruction and the final destruction of a typical Western frontier settlement: a treeless prairie town in the Dakotas dependent on a nearby gold mine and populated by saloon women, sharpshooters, a villain of apocalyptic proportions, immigrants, stage drivers, miners and a token Indian. Within this scenario, the main protagonist, Blue, makes futile attempts to establish civilization and win over the heroine.

To begin with, Welcome to Hard Times fits into Leslie Fiedler's definition of the New Western and Christine Bold's definition of the anti-Western novel by demythologizing the Western formula and portraying how violence and lawlessness prevail over progress and illusions. As Bevilacqua argues, Doctorow's method "involves 
underplaying some components of both the traditional and twentieth-century formulas while bringing others to the foreground so that the main elements of his novel simultaneously resemble the familiar icons of the frontier legends and diverge significantly from them" (Bevilacqua 1989: 82).

What the reader experiences is a cyclical recurrence of violence and destruction rather than a progressing civilization as the villain from Bodie, Clay Turner, razes to the ground, not once but twice, an apparently flourishing frontier town for the simple joy of it. The survivors include Blue, a coward and self-appointed mayor-narrator who fails to stand up and challenge the villain; Molly, a former prostitute, raped by the Bad Man and left half-dead in the wreckage and Jimmy, an eleven-year-old boy whose father is killed by the Bad Man in the raid.

Furthermore, this "ceaseless, motiveless, unrepentant destruction" of the frontier town is brought about by a drunk white man with "liquor in his soul and a gun in his claw" (Hard Times 29), that is, the formerly lionized "social bandit" (Zins 1976: 3), and not by rebellious Indians. In fact, the only surviving Indian and/or "injun" in the novel, the deaf-and dumb Pawnee John Bear, remains an exemplary healer and self-sufficient Indian whose presence might suggest the previous existence of a vanished race now either exterminated or reduced to domesticity (Bevilacqua 1989: 83).

The typical optimism of the classic Western are depicted here as deceptive and illusive as the atypical 'family of three,' brought together by fate rather than free will, miraculously survive the notorious Dakota winter. The main hero of the novel, Blue, apparently an agent of civilization but "ludicrously naïve, self-deluded, impotent in the face of evil" (Morris 1991: vii), seems to be more talented in convincing the random travelers and fortune seekers to settle down in his utopian town than in handling guns and protecting his townspeople or his heroine. As such, he falls short of the Western hero's main characteristic, that is, the exceptional ability to handle guns, as Blue's allusion to the Colt 45 suggests:

Now the saying is common that Sam Colt made men equal. But it is true then our town wouldn't have burned up in the rain; instead that Bad Man would have been buried with due honors and a proper notice sent to the Territory Office. He would have had a hole in his chest, or his back, and the one who shot him would have Avery standing him a drink and maybe redheaded Flo and Molly smiling his way. Colt gave every man a gun, but you have to squeeze the trigger for yourself. (Hard Times 32)

30 In fact, Blue's inability to perform heroic deeds is parodied when he is brought face to face with the villain and prefers getting drunk to drawing his gun. Thus, Blue, unlike his classic counterpart, represents values usually reserved for the female heroine, such as the desire for being part of a safe, settled community in the West as the best way to prevent the appearance of Bad Men. Even his decision to father the orphaned Jimmy and symbolically marry the former prostitute, Molly, is taken out of social and communal responsibility. In fact, such false ideals initially force him to turn to bookrecording in the first place, hoping that the town would someday apply for statehood and his records would come in handy: "The town had no promoter, you see, and there were no records for anything. If it ever got big enough to be listed or if the Territory ever needed names for a statehood petition, why I had these documents" (Hard Times 101). Likewise, he decides to teach Jimmy how to read and write rather than how to shoot, against the wishes of Molly. 
31 As far as the heroine of the novel, Molly, is concerned, although she is named after The Virginian's sweetheart she bears no resemblance whatsoever to the classic heroine of the TV series. Molly, originally an Irish immigrant from New York, became a prostitute in the west as she "couldn't bear bein' a maid, I was too proud to say 'Yes Mum"' (Hard Times 16), thus being tainted and morally inferior to the classic, virginal 'schoolmarms' of the genre. Even her apparent attachment to a symbolic cross, as the character Zar rightly observed: “. . . she has sharp nails for a believer" (Hard Times 43), reveals nothing about her religious tendencies. "She clings to a cross on a chain necklace as if invoking the western heroine's gospel of love and reconciliation, for her the cross is less the symbolic representation of a viable and sustaining world view than the talisman of a futile approach to life" (Bevilacqua 1989: 86).

Moreover, Molly becomes the agent of cyclical violence rather than of a peaceful settlement by nourishing hatred for Blue and bringing Jimmy up with shooting skills. Therefore, throughout the novel, Molly acts as an intuitive counterbalance and opposition to Blue's overt optimism in the frontier myths of progress by egotistically seeking protection at all costs: “'Oh Major', she said, 'if this town stretched four ways as far as the eye could see, it would still be a wilderness' .. . 'Blue, for God's sake let's leave this place!' . . . 'It's not safe anymore; I swear we've got to get out of here! . . .God, you're a fool, Mayor. You always was a fool"' (Hard Times 144,148). In addition, Blue's reactions to her pleadings further reveal their incompatibility as a family unit. Such divergence actually undermine the family and eventually render it non-functional and non-existent as Molly's hatred for Blue deepens and her anxiety about a second return of The Bad Man becomes unbearable.

Thus, Molly mocks Blue for being a coward: "Were you any good with a gun Mayor maybe you could teach the boy some manliness" (Hard Times 153), and she gets the Sheriff, a crazy shooter called Jenks, to teach Jimmy how to handle guns. Jimmy himself listens "to everything she said like it was gospel, no matter what she spoke of or how many times she'd said it before," (Hard Times 151). In fact, when Jenks starts teaching Jimmy how to shoot, it becomes clear that Blue's "surrogate family" stands as a parody of the family in Schaefer's Shane. Unlike the symbolic family in Shane, "here the husband is a coward, the wife - married to him symbolically by the torn wedding dress she wears throughout the action - is a prostitute, and the boy, born to them through violence, is being turned into a rabid hater of all men by his 'mother"' (Bold 1987: 159).

Finally, Blue tries to commit a once-in-a-life heroic act by facing bravely and intelligently the return of The Bad Man whose coming he sees as "the scythe swings back" (Hard Times 187) and whose presence he cannot escape: "He never left the town, it was waiting only for the proper light to see him where he's been all the time" (Hard Times 195). Unfortunately, like Jenks who lost his life foolishly confronting Clay Turner face to face, Blue's desire to become "Molly's last fool" (Hard Times 202) proves fatal in other unpredictable ways even though he manages to trap and beat the villain unconscious. In fact, he had not taken into account Molly's accumulated desire for revenge. Blue's long-nourished illusions to strengthen once again his family ties and his town go up in flames when his inability to satisfy Molly's sadistic obsession proves fatal for both Molly and Turner, symbolically locked in a final, deadly embrace: "It was the moment Turner's arms had closed around Molly as if in embrace. My hand was over the muzzle of the gun but the blast killed them both. Fainting, I could hear people outside 
tipping over the water tank, and it was that sound I listened to, the spread of water, an indecent gush" (Hard Times 209).

The end of the novel therefore portrays the destruction of established civilization on the one hand, and of the preconceived notions of frontier myths on the other. The unstoppable cycle of violence is proven as Jimmy runs away to become another Bad Man and wreck other outposts of civilization: "He's gone, he is riding hard, that mule and rig will take him places, another Bad Man from Bodie, who used to be Fee's boy" (Hard Times 211).

As The Bad Man "turns out to be a truer adoptive father than Blue after all, for he represents a sounder approach to the reality of the Dakota Territory" (Saltzman 1983: 78), is Welcome to Hard Times a better source on how the West was lost or won? By highlighting the prevalence of violence in the West, the novel becomes a more revealing piece of literature about the legacy of westward expansion than the traditional Western, where violence is often depicted as instrumental rather than an essential part of the settlement of the West.

6. The West as Fraud

It is argued here that the deconstruction of the West and the Western reaches a climax in the utilization of parody as the ultimate means to satirize the erroneous and unsustainable mythology of the region. As such, it makes more sense to judge westward expansion or the settlement of the West not only as a futile economic venture but also as a degrading and destructive experience, since the region turns out to have no resemblance to its promotion brochures. In addition, the so-called "heroic" pioneer or rugged individual turns out to embody and carry west all the materialist and monopolist tendencies which his peers in the East apparently suffer from. Thus, the novel depicts "the predominance of money, greed and force on the frontier . . . the practice of capitalism, of hucksterism and exploitation [which] underlie and belie the more noble myths of conflict on the frontier" (Gross 1980:84). As a result, the western experience in the novel becomes a never-ending struggle for survival against unpredictable forces such as the economic interests of Eastern investors and an unwelcoming landscape and climate, as Blue's narration points out. The settlers are trapped in their own preconceived capitalist illusions of profits and utopian idealism.

To start with, Welcome to Hard Times stands as a criticism of Turner's thesis on the West. The archetypal villain, Clay Turner, could be argued to stand as an ironic reference to the historian Turner himself as the novel questions the foundations of democracy and its uniqueness by depicting the demise of a frontier town in the second half of the nineteenth century. In addition, most of the characters are in fact immigrants who have come West due to false frontier myths of progress, freedom and the hope to make a fresh start and strike it rich (Bevilacqua 1989: 87-88). Issac Maple, the grocery store owner, has come West encouraged by a vague letter from his brother: "'Come along when you can, there's room out there fer two"' (Hard Times 79). Zar, the Russian whoremaster and the exemplary entrepreneur, wraps up all the exploitative and monopolist tendencies of the western experience in one single paragraph:

Frand. . . I come West to farm. . . but soon I learn, I see. . . farmers starve. . . only people who sell farmers their land, their fence, their seed, their tools. . . only these people are rich. And is that way with everything. . . not miners have gold but salesman of burros and picks and pans. . not cowboys have money but saloons who sell to them their drinks, gamblers who play with them faro. . . not those who look for money but those supply those to look. These make the money. . . So I sell my 
farm. . . and I think. . . what need is there I shall fill it. . . and I think more than picks and pans, more than seed, more even than whiskey or cards is need for Women. And then I meet widow Adah, owner of tent. . . And I am in business. (Hard Times 63-64)

Due to such false mythology, it seems as if the town is prospering and bustling with new settlers, miners, and with the prospects of a railroad hanging in the air. That, in fact, is enough to raise Blue's hope to re-start recording the accounts: "Molly was right, I would welcome an outlaw if he rode in. I felt anyone new helped bury the past. Swede's coming even put in my mind a thought I wouldn't have tolerated before - to keep a record again, to write things down" (Hard Times 123). The town now "sports" even a jail of its own with the crazy but illiterate shootist, Jenks, appointed as the town's Deputy Sheriff. It seems as if the law has been restored, or has it? Blue observes the growth of the town with apprehension as more jobseekers keep turning up: "These people are lying around here spending their cash and they're not making any. We are grabbing everything they have" (Hard Times 177).

However, it takes more than illusions or goodwill to make it in the West or build a town in the middle of nowhere as other factors, mainly economic interests, tend to work to the disadvantage of the settlers:

Economic interests are as capricious as natural ones, and as potentially devastating; the surest occupations on the frontier are bartending, whoring, and grave digging. Survival is reserved for strong men and scavengers (Saltzman 1983: 76)

41 The temporary success of Hard Times due to the mining and possible railroad soon vanishes. As a result, the bulk of people remain, at large, uncontrollable. Therefore, the looting initiated by the miners and drifters makes them all potential Bad Men. In fact, the Bad Man from Bodie seems to be among the looters, as if he had never left the town. Eventually, the frontier town joins the long line of ghost towns, a typical phenomenon in the West where apparently prosperous towns disappear from the face of the earth overnight due to sudden eruptions of violence which eventually scare the investors away and cause the failure of all economic ventures. But the fundamental nature of economic relationships also lies behind this phenomenon:

Every relationship we come across in the novel is based on a series of transactions rather than on emotional ties. (That Blue composes on ledgers is particularly significant, for in such a vicious, Hobbesian environment, only the most tangible system of debits and credits can be trusted)... To make it as a man you must be rich, unscrupulous, or handy with a gun: to make it as a woman you must prostitute yourself to powerful men. (Saltzman 1983: 77)

Blue, despite his noble aspirations to rebuild the town from scratch, is aware of his personal material profits that might arise from it, and he strikes a deal with the coach driver Alf "to handle the Express business for the town" and the mailing of letters at "three percentages on all monies" (Hard Times 81-82), thereafter investing and lending his money with interest: "A couple I lent money to straight off at a rate of one percent, and by noon I had gotten rid of all my money except what I needed to keep the three of us. . . My mind was teeming with plans to keep the temperature down and the money fluent" (Hard Times 175-176). In addition, Zar, who epitomizes the money-conscious entrepreneur, has come west to make money by trading what is mostly needed: liquor and women. When Blue describes the future prospects for the town Zar just responds: “'Ah, you have not the merchant's 
nose. You know what I smell? The money!"' (Hard Times 55). Once settled, he expects the town folks to keep trading among themselves and visiting his girls the way he pays for their goods and services. Later on he exactly develops a dislike and eventually a grudge against Issac Maple, the grocery owner, for breaking this code of transactions. Another factor which prevents civilization from laying deep roots in Hard Times regards the unwelcome and discouraging vastness of the American Plains and the harsh, unbearable weather conditions (Bevilacqua 1989: 89). The isolated inhabitants had to survive in makeshift dug-outs and tents during a freezing, windy Dakota winter of never-ending blizzards and snow falls before they could found their (doomed) town. Doctorow stated the following in an interview:

With Welcome to Hard Times, it was just a sense of place which moved me tremendously. It was the landscape. I loved writing about it, imagining it. I had never been West. Halfway through the book, it occurred to me that maybe I ought to make sure it really was a possible terrain. I went to the library and read a geography book by Walter Prescott Webb-a marvelous book called The Great Plains. Webb said what I wanted to hear: no tress out there. Jesus, that was beautiful. I could spin the whole book out of one image. And I did. (McCaffery 1999: 79-80)

Even Blue begins his description of the town by mentioning the vastness of the Dakota Territory: "there is nothing but miles of flats" (Hard Times 3), later on arguing that "it was weather that wouldn't let you settle" (Hard Times 90) and that "There had to be an end to winter or an end to us" (Hard Times 111). Issac Maple, for instance, claims not to have seen a "tree in seven days" (Hard Times 80). Zar, too, when told about some Christmas celebration, reacts: "Wal wal, I tell you - only the spring shall I celebrate" (Hard Times 102). However, none of them has suffered more than Helga, Swede's wife, who seems to have lost her mind because of the Plains' climate, especially the unbearable wind.

Spring does bring some surplus and apparent welfare: "And I tell you we commenced to eat good... and it wasn't before long the flesh filled in between the bones and we began to look human once more" (Hard Times 114) But this is still the boom and bust economy so typical in the West, and Molly senses this strongly: "'All these fools have come like buzzards after the smell of meat"' (Hard Times 143). The others get the message a little bit too late. Everyone seem to be aware of the risks they are running into but economic profits and future prospects keep them there. Blue, like the mine owners, unintentionally delayed the fulfilment of Molly's prophecy by keeping the expected letter, which would verify the failure of the mine, in the drawer for two extra weeks. Naturally, they all blame Blue for their bankruptcy. Issac Maple accuses him of intentional fraud: "I said it would come to this, I knew it would. I'm ruined! Ye sure sold me, ye surely traded me!" (Hard Times 188). Zar laments the loss of his investments: "My hotel! My beautiful hotel! From where shall come the customers?" (Hard Times 189). Even Blue, towards the end of his ledgers, seems to accept responsibility, blaming his own shortsightedness. Eventually, most of the settlers, after being ruined economically, lose even their own lives, leaving the deadly wounded narrator only enough time to note down the destructive events.

Overall, Doctorow fully reverses the expectations of the classic idea of the West as the land of harmony and progress, where virtue is rewarded and evil punished, in order to highlight the violent, fraudulent and destructive character of the settlement as essential elements of the New Western. By making use of the emerging paradigms of 
the 1960s, Doctorow provides an intriguing yet appalling image of the West and in doing so gets closer to the realities of the western experience.

7. Conclusion

The main purpose of the current study remains the lasting impact of the legacy of the 1960s through New Western or Post Western literature, a phase initiated as early as 1960 by E. L. Doctorow's Welcome to Hard Times. This shift did not come onto the scene unheralded but was rather well-grounded in the general mistrust towards popular mythology, and it fully reflected the crisis of representation which gathered speed in the early 1960s, which went on to shatter old mentalities and notions, and which defined a decade that we by now tend to take for granted. Welcome to Hard Times serves different functions: it both revitalizes the novel-writing process through a fusion of self-reflexive and classic Western elements, and it creates 'real fiction' by parodying genre clichés and questioning the legacy of the westward expansion itself.

\section{BIBLIOGRAPHY}

Arnold, Marilyn. "History as Fate in E. L. Doctorow's Tale of a Western City." South Dakota Review 18 (Spring 1980): 53-63.

Barth, John. The Friday Book: Essays and Other Nonfiction. Baltimore: The Johns Hopkins University Press, 1997.

Bevilacqua, Winifred Farrant. “The Revision of the Western in E. L. Doctorow's Welcome to Hard Times," American Literature 61 (March 1989): 78-95.

Bold, Christine. Selling the Wild West: Popular Fiction 1860 to 1960. Bloomington: Indiana University Press, 1987.

Buscombe, Eduard. Back in the Saddle Again: New Essays on the Western. London: British Film Institute, 1998.

Cawelti, John G. The Six-Gun Mystique Sequel. Bowling Green: Bowling Green State University Popular Press, 1999.

Doctorow, E. L., Welcome to Hard Times, N. Y: A Plume Book, 1996.

- - -. "False Documents". Trenner, Richard. Ed. Essays \& Conversations. Princeton, New Jersey: Ontario Review Press, 1983.

Federman, Raymond. Critifiction: Postmodern Essays. Albany, N Y: State University of New York Press, 1993.

Fiedler, Leslie. The Return of the Vanishing American, New York: Stain and Day, 1968.

Folsom, James K. The American Western Novel, New Haven: College and University Press, 1966.

Friedl, Herwig and Dieter Schulz. "A Multiplicity of Witness: E. L. Doctorow at Heidelberg." Christopher D. Morris. Ed. Conversations with E. L. Doctorow, Jackson: University Press of Mississippi, 1999. 
Gross, David. "Tales of Obscene Power: Money and Culture, Modernism and History in the Fiction of E.L. Doctorow." Genre 13 (1980): 71-92.

Harpham, Geoffrey Galt. “E.L. Doctorow and the Technology of Narrative.” PLMA 100 (1985): 81-95.

Harter, Carol C., and James R. Thompson. E. L. Doctorow. Boston: Twayne Publishers, 1990.

Hassan, Ihab. Rumors of Change: Essays of five Decades. Tuscaloosa: University of Alabama Press, 1995.

Hutcheon, Linda. The Politics of Postmodernism. N Y: Routledge, 1989.

- - -. The Poetics of Postmodernism. N.Y: Routledge, 1988.

Jameson, Fredric. "Periodizing the 1960s" in The Ideologies of Theory: Essays, 1971-1986. Minneapolis: University of Minnesota Press, 1988.

Lyotard, Jean-Francois. The Postmodern Condition: A Report on Knowledge. Minneapolis: University of Minnesota Press, 1991.

Marwick, Arthur. The Sixties. New York: Oxford University Press, 1998.

McCaffery, Larry. “A Spirit of Transgression.” Christopher D. Morris. Ed. Conversations with E. L. Doctorow. Jackson: University Press of Mississippi, 1999.

Morris, Christopher D. Models of Misrepresentation: On the fiction of E.L. Doctorow. Jackson: University Press of Mississippi, 1991.

Parks, John G., "The Politics of Polyphony: The Fiction of E. L. Doctorow.” Twentieth Century Literature 37 (Winter 1991): 454-463.

Saltzman, Arthur. “The Stylistic Energy of E. L. Doctorow.” In Trenner, Richard. Ed. Essays \& Conversations. Princeton, New Jersey: Ontario Review Press, 1983.

Williams, John. Fiction as False Document: The Reception of E. L. Doctorow in the Postmodern Age. Columbia: Camden House, 1996.

Zins, Daniel L. "E.L. Doctorow: The Novelist as Historian.” Hollins Critic 36 (December 1976).

\section{NOTES}

1. For an all-encompassing overview of the 1960 s see Fredric Jameson, "Periodizing the 60s" in Jameson, The Ideologies of Theory: Essays 1971-1986 (Minneapolis: University of Minnesota Press, 1988).

2. Arthur Marwick's The Sixties: Cultural Revolution in Britain, France, Italy, and the United States, c. 1958-c.1974 (New York: Oxford University Press, 1998) remains the best and the most detailed source regarding the era.

3. Marwick provides the following definitions in this context: Cross-Over: The term implies the intermixing of elite and popular art, already most obviously apparent in Pop Art and nouveau réalisme. The Blurring of Boundaries: Not this time the blurring between elite and popular art, but that between the different individual forms: between art and sculpture, between art and poetry, between music and drama, and so on ... Conceptualism: The heading is a vague one, yet absolutely central in that it pushes towards ultimate extremes in privileging the idea or concept over any direct representation, and in invoking the unavoidable involvement of language (the only way 
in which concepts can be expressed, or made explicit)... Indeterminacy or the Aleatoric: These elaborate words cover the notions of chance elements being incorporated into works of art and of there being uncertainty (in the way Eco identified) about the meaning or meanings of particular works, with the reader, viewer, listener having a part in selecting meanings ... Participation: There is a link here to the previous heading, but the participation of reader, viewer, listener, or audience could be so pronounced as to become a major element in a work, as in certain types of theatre calling for audience-participation, or in an assemblage composed of mirrors ... Technology: Mobile assemblages, assemblages with flashing lights, assemblages made out of the products of technology were all obvious examples, while musique concrète (taped music based on natural sounds), then electronic music (produced entirely by electronic means), were particularly stunning ones. Drug-induced perceptions... Psychedelic 'light shows' became an almost essential adjunct to counter-cultural rock/pop music. Radical Criticism, Revolutionary Stances: A 'work of art' (the phrase itself was said to be a bourgeois one) was not to be distinguished from a philosophical tract, or, for that matter, from a piece of historical writing. All could be described as 'experiments', or 'interpretations', or 'texts'. Social and Cultural Practices (Particularly 'Counter-Cultural' Ones) as 'Spectacle' : However revolutionary or 'counter-cultural' in attention, it was very difficult for practitioners of the arts to escape from the circumstance that everything was being produced within a society in which there was a steadily growing appetite for the new, and an entire commercial and technological apparatus devoted to focusing attention on, and marketing, the daring and exciting." (Marwick 1998: 316-318)

4. The phrase, which refers to reality being "locked away," comes from Fredric Jameson's The Prison-House of Language: A Critical Account of Structuralism and Russian Formalism (Princeton: Princeton University Press, 1972).

\section{AUTHOR}

\section{ARTHUR JAUPAJ}

Artur Jaupaj, University of New York/Tirana, Albania 